Research article

Open Access

\title{
Chemical Modification of Pectins, Characterization and Evaluation for Drug Delivery
}

\author{
Manish S. Bhatia * ${ }^{1}$, Rameshwar Deshmukh ${ }^{2}$, \\ Praffula Choudhari ${ }^{1}$, Neela M. Bhatia ${ }^{1}$
}

1 Department of Pharmaceutical Chemistry, Bharati Vidyapeeth College of Pharmacy, Shivaji University, Near Chitranagri, Kolhapur, 416 013, Maharashtra, India.

2 Department of Pharmaceutics, Bharati Vidyapeeth College of Pharmacy, Shivaji University, Near Chitranagri, Kolhapur, 416 013, Maharashtra, India.

* Corresponding author. E-mail: bhatiamanish13@gmail.com (M. S. Bhatia)

Sci Pharm. 2008; 76: 775-784

doi:10.3797/scipharm.0805-23

Published: October $17^{\text {th }} 2008 \quad$ Received: May $28^{\text {th }} 2008$

Accepted: $\quad$ October $16^{\text {th }} 2008$

This article is available from: http://dx.doi.org/10.3797/scipharm.0805-23

(C) Bhatia et al; licensee Österreichische Apotheker-Verlagsgesellschaft m. b. H., Vienna, Austria.

This is an Open Access article distributed under the terms of the Creative Commons Attribution License (http://creativecommons.org/licenses/by/3.0/), which permits unrestricted use, distribution, and reproduction in any medium, provided the original work is properly cited.

\begin{abstract}
The aim of this work was the chemical modification of pectins by limited acetylation of their free hydroxyl groups to yield high ester pectins and to investigate its swelling and erosion behavior along with the effect on the release pattern of drugs. Ibuprofen as a weakly acidic drug was formulated as tablets using chemically modified pectin and its impact on drug release was studied. Optimum concentrations of the modified pectin in such a system protect the tablet throughout the gastrointestinal tract (GIT) for 10-12 hrs. The pectin modified with acetylating agent was found to be promising to modify the release of drugs which are to be delivered throughout GIT. Drug dissolution studies were carried out in buffers of $\mathrm{pH} 1.2$ and 6.8 and the system was designed based on the total GIT transit time concept.

This article reviews physicochemical characterization of chemically modified pectins, correlation of the physicochemical characteristics with the drug release pattern of ibuprofen and the potential use of chemically modified pectin for modified release dosage forms.
\end{abstract}

\section{Keywords}

Pectins • Chemical modification • Ibuprofen • Release profile 


\section{Introduction}

Pectin occurs naturally in the cell walls in most of the higher plants. Apple, quince, plume, gooseberry, oranges, cherries and grapes contain pectin. It is an essential component in the initial growth and in the ripening process and has been found to be useful in area of drug delivery $[1,2]$. Often this is a waste material from food and fruit processing industry [3]. Pectin is a complex polysaccharide consisting mainly of esterified D-galacturonic acid residue in an $\alpha(1-4)$ chain. The acid groups along the chain are largely esterified with methoxy groups in the natural product [4]. Pectin is highly hydrophilic in nature. Hydrophilic matrices are generally used for the oral drug delivery and for the preparation of modified release formulation [5]. The release from the hydrophilic matrix is controlled by the viscous layer barrier around the tablet that opposes the penetration of solvent into the tablet [6]. Nowadays, pectin is gaining importance as a polymer for modified release drug delivery formulation because of its low production cost and readily availability [7]. However, the major challenge of using pectin for the development of modified drug formulation is to overcome its solubility in aqueous medium which may contribute to the undesirable premature and local release of the active principle from the polysaccharide matrix [8-9]. One of the options to reduce the high solubility of polysaccharides could be to chemically modify them without affecting their biodegradability [10-13]. Pectins can be modified by saponification catalysed by mineral acids, bases, salts of weak acids, enzymes, concentrated ammonium systems and primary aliphatic amines [14]. In this work, we propose the chemical modification of pectin by the reaction with phenyl acetyl chloride and acetyl chloride. The objective of this modification was to reduce the polarity of pectin by reducing the number of free hydroxyl groups and to study the release of the ibuprofen from tablets prepared using this modified pectins [15]. Ibuprofen is a non-steroidal antiinflammatory drug which is used to reduce fever and treat inflammation caused by many conditions such as headache, arthritis or toothache. In this work, we briefly describe the current knowledge about the chemical structure of pectin and which benefits could be achieved with respect to formulation parameters after its chemical modification.

\section{Results and Discussion}

\section{Swelling/ Gelling and Solubility parameters}

Pectin has been used for designing sustained release and controlled release dosage forms but its application has been limited because of its solubility and swellability in water. This does not permit its use in larger quantities which may be required to sustain the release of drugs at a desired extent. In this work, we have made an attempt to decrease the polarity of this polymer with the aim to limit its hydrophilic interactions and provoke a higher degree of hydrophobicity and lipophilicity.

Tab. 1. Gelling or swelling factor

\begin{tabular}{llllll}
\hline $\begin{array}{l}\text { Quantity of } \\
\text { polymer }\end{array}$ & Solvent & \multicolumn{4}{c}{$\begin{array}{c}\text { Quantity of water uptake (swelling factor \%) } \\
\text { Method A }\end{array}$} \\
& & Product 1 & Product 2 & Product 1 & Product 2 \\
\hline \multirow{2}{*}{$100 \mathrm{mg}$} & Distilled & $0.205 \mathrm{~g}$ & $0.139 \mathrm{~g}$ & $0.210 \mathrm{~g}$ & $0.149 \mathrm{~g}$ \\
& water & $(205)$ & $(139)$ & $(210)$ & $(149)$ \\
\hline
\end{tabular}

a $\% \mathrm{w} / \mathrm{w}$ of $\mathrm{g}$ of water absorbed per $100 \mathrm{mg}$ of chemically modified polymer 
The extent of chemical modification was quantitatively limited to an extent which would help retain the swellability but at the same time improve adhesive properties. Pectin itself is completely soluble in water and insoluble in chloroform and methanol while from the results of water uptake and solubility studies, it appears that the targeted chemical modification of pectin delays solubilisation in water and thus proves itself as a candidate auxiliary agent to extend the release of drugs. A decrease in water solubility concurrent with an increase in organic solvent solubility was observed for all the modified polymers but the product 1 from method $B$ had retained its swelling properties to a greater extent (Table 1 and Table 2).

Tab. 2. Solubility parameters

\begin{tabular}{llllll}
\hline $\begin{array}{l}\text { Quantity } \\
\text { of polymer }\end{array}$ & Solvent & \multicolumn{2}{c}{$\begin{array}{c}\text { Quantity of modified polymer dissolved } \\
\text { Method A }\end{array}$} & \multicolumn{2}{c}{$\begin{array}{c}\text { Method B } \\
\text { Prothet 2 }\end{array}$} \\
\cline { 2 - 6 } & & Product 1 & Product 2 & Product 1 & Product 2 \\
\hline $100 \mathrm{mg}$ & Distilled water & $62 \mathrm{mg}$ & $52 \mathrm{mg}$ & $57 \mathrm{mg}$ & $61 \mathrm{mg}$ \\
$100 \mathrm{mg}$ & Chloroform & $10 \mathrm{mg}$ & $08 \mathrm{mg}$ & $05 \mathrm{mg}$ & $28 \mathrm{mg}$ \\
$100 \mathrm{mg}$ & Methanol & $06 \mathrm{mg}$ & $13 \mathrm{mg}$ & $12 \mathrm{mg}$ & $21 \mathrm{mg}$
\end{tabular}

Acid value, ester value and saponification value of product 1 from batch $B$

Tab. 3. Acid, ester and saponification values of polymer B1 in comparison to unmodified pectin

\begin{tabular}{llll}
\hline Polymer & Acid value & Saponification value & Ester value \\
\hline Pure pectin & 168.30 & 227.20 & 58.90 \\
Modified polymer & 44.88 & 137.44 & 92.56
\end{tabular}

Acetylation of pectin with phenacetylbromide for $2 \mathrm{~h}$ reduced the acid number to $25 \%$ and the saponification value by $40 \%$. Accordingly, the ester value increased by $57 \%$.

\section{Tablet characteristics:}

Due to their stickiness the composite powders of the tablet formulation could not be compressed directly into a core tablet. Consequently, ibuprofen, lactose, magnesium stearate, modified pectin (product 1 from batch B) and HPMC K100M were processed by wet granulation. The physical properties of ibuprofen matrix tablets such as diameter, thickness, weight, friability and hardness of modified pectin B1(product 1 from batch $\mathrm{B}) / \mathrm{HPMC}$ K100M compression coated tablets are given in Table 4. 
Tab. 4. The physical properties of ibuprofen matrix tablets $(n=3)$

\begin{tabular}{|c|c|c|c|c|c|}
\hline Batches & $\begin{array}{l}\text { Weight } \\
\text { (mg, } \pm \text { S. D.) }\end{array}$ & $\begin{array}{l}\text { Diameter } \\
\text { (mm, } \pm \text { S. D.) }\end{array}$ & $\begin{array}{l}\text { Thickness } \\
\text { (mm, } \pm \text { S. D.) }\end{array}$ & $\begin{array}{l}\text { Friability } \\
(\%)\end{array}$ & $\begin{array}{l}\text { Hardness } \\
\left(\mathrm{Kg} / \mathrm{cm}^{2}, \pm \mathrm{S} \text {. D.) }\right.\end{array}$ \\
\hline B1 & $285 \pm 4.70$ & $8.16 \pm 0.00$ & $4.81 \pm 0.01$ & 0.05 & $4.80 \pm 0.11$ \\
\hline B2 & $259 \pm 1.40$ & $8.17 \pm 0.00$ & $4.67 \pm 0.00$ & 0.04 & $4.03 \pm 0.11$ \\
\hline B3 & $222 \pm 7.00$ & $8.10 \pm 0.00$ & $3.80 \pm 0.00$ & 0.03 & $3.26 \pm 0.16$ \\
\hline B4 & $262 \pm 7.00$ & $8.11 \pm 0.11$ & $3.47 \pm 0.02$ & 0.03 & $3.93 \pm 0.11$ \\
\hline B5 & $282 \pm 7.10$ & $8.11 \pm 0.00$ & $3.35 \pm 0.00$ & 0.02 & $3.73 \pm 0.32$ \\
\hline B6 & $286 \pm 4.90$ & $8.17 \pm 0.00$ & $5.07 \pm 0.00$ & 0.02 & $4.70 \pm 0.16$ \\
\hline B7 & $206 \pm 0.90$ & $8.14 \pm 0.01$ & $3.59 \pm 0.35$ & 0.04 & $3.60 \pm 0.14$ \\
\hline B8 & $225 \pm 0.70$ & $8.15 \pm 0.00$ & $4.15 \pm 0.00$ & 0.03 & $3.73 \pm 0.18$ \\
\hline B9 & $165 \pm 1.20$ & $8.11 \pm 0.01$ & $3.10 \pm 0.01$ & 0.03 & $3.83 \pm 0.25$ \\
\hline
\end{tabular}

It was found that crushing strength of compression coated matrix tablets was dependent on modified pectin (product 1 from batch B)/HPMC K100M polymer ratio. When HPMC $\mathrm{K} 100 \mathrm{M}$ ratio in polymer mixture increased that of modified pectin (product 1 from batch $\mathrm{B}$ ), the crushing strength of coated tablets was increased (see Table 7). HPMC K100M provides mechanical strength of the matrix tablet. All tablets complied with the pharmaceutical quality control standards.

\section{Result of dissolution studies}

A factorial design $3^{2}$ ratio was used to study the effect of modified pectin and HPMC on the release profile of an acidic drug in $0.1 \mathrm{~N} \mathrm{HCl}$ and phosphate buffer $\mathrm{pH}$ 6.8. Regression analysis data are presented in Table 6 . From the values of slope (n) and the coefficient of correlation ( $r$ ), it is concluded that most of times the system follows matrix type of release based on principle of diffusion of drug. The $t_{50} \%$ studies clearly reveal sustained release of ibuprofen because of HPMC and modified pectin (product 1 from method B). The contribution of modified pectin was assessed to be significant in sustaining the release of drug in comparison to HPMC alone.

Tab. 6. Regression analysis data for release of ibuprofen from compacts

\begin{tabular}{|c|c|c|c|c|c|c|c|}
\hline \multirow[b]{2}{*}{ Batches } & \multicolumn{2}{|c|}{$0.1 \mathrm{~N} \mathrm{HCl}$} & \multirow[b]{2}{*}{$\begin{array}{l}\text { Best fit } \\
\text { model }\end{array}$} & \multicolumn{3}{|c|}{ Phosphate buffer pH (6.8) } & \multirow[b]{2}{*}{$\begin{array}{l}\mathbf{t}_{50} \% \\
\text { (h) }\end{array}$} \\
\hline & $\mathbf{n}$ & k & & n & k & $\begin{array}{l}\text { Best fit } \\
\text { model }\end{array}$ & \\
\hline B1 & 0.72 & 5.72 & Matrix & 0.74 & 1.24 & Matrix & 1 \\
\hline B2 & 0.46 & 2.41 & Matrix & 0.05 & 0.64 & Zero order & 5 \\
\hline B3-B6 & NA & NA & NA & NA & NA & NA & NA \\
\hline $\mathrm{B} 7$ & NA & NA & NA & 0.30 & 1.02 & Zero order & 2 \\
\hline B8 & 0.53 & 1.69 & Peppas & NA & NA & NA & NA \\
\hline B9 & 0.38 & 1.37 & Peppas & NA & NA & NA & NA \\
\hline
\end{tabular}

NA ... not applicable. 
The optimum composition of the formulation employing the modified pectin scores over HPMC alone in terms of ability to sustain the release, the binding ability and the robustness for formulation processing. Formulations containing the selected modified polymer and no HPMC wherein all other components of the formulation were not changed provoked complete release of the drug in less than $30 \mathrm{~min}$. The same results were observed when HPMC was used without the modified polymer. Thus, the designed formulation meets the desired release profile only at a specific ratio of the two polymers where both excipients contribute to yield the desired release profile. Experiments employing various chemically modified pectins to reduce the number and types of polymers required to design a formulation with a desired release profile are in progress. The observations pertaining to formulation characteristics using neutral and basic drugs are in the process of completion.

\section{Experimental}

Ibuprofen was kindly gifted by Block Pharmaceuticals, (Kolhapur). Hydroxypropyl methylcellulose K100M (HPMC K100M) was Dow Chemical Product and kindly gifted by Colorcon Asia Pvt. Ltd. (Goa). Pectin was kindly gifted by Krishna Pvt. Ltd. (Jalgaon). All other chemicals used for analysis were of analytical grade. A PC based Jasco V-530 recording spectrophotometer with spectral bandwidth (resolution) of $2 \mathrm{~nm}$ and wavelength accuracy of $\pm 0.3 \mathrm{~nm}$ (with automatic wavelength correction) was employed for all measurements using a matched pair of $10 \mathrm{~mm}$ quartz cells. A Shimadzu AY 120 analytical balance was used for weighing and a PCi ultrasonicator for ultrasonication. Dissolution test apparatus USP type II (model TDT-08L, Electrolab, India) was used for dissolution test. Single punch compressor was used for preparation of tablets.

\section{Procedure for pectin modification:}

The pectin was modified by two different techniques as given below.

Method A: Using acetyl chloride.

Product 1:

A weighed quantity of $10 \mathrm{~g}$ of crude pectin was taken in a flask placed on a magnetic stirrer. Freshly prepared $40 \% \mathrm{v} / \mathrm{v}$ acetyl chloride in ethanol was transferred into burette and $5 \mathrm{ml}$ were added dropwise under stirring over a period of $30 \mathrm{~min}$. The product was washed with water, filtered and dried in a hot air oven at $37^{\circ} \mathrm{C}$.

\section{Product 2:}

$10.0 \mathrm{~g}$ pectin was gradually added into a flask containing $5 \mathrm{ml}$ of freshly prepared $40 \% \mathrm{v} / \mathrm{v}$ acetyl chloride in ethanol over a period of $90 \mathrm{~min}$. The product was filtered, washed and dried in a hot air oven at $37^{\circ} \mathrm{C}$.

Method B: Using phenyl acetyl chloride.

Procedure for preparation of Phenyl acetyl halide:

$1.636 \mathrm{~g}(0.9772 \mathrm{ml}, 0.00136 \mathrm{~mol})$ of redistilled thionyl chloride were placed in a $100 \mathrm{ml}$ two-necked flask equipped with a dropping funnel and a reflux condenser connected at the 
top to the gas absorption trap. and gently heated on water bath. $1 \mathrm{~g}$ of phenyl acetic acid $(1.004 \mathrm{ml}, 0.01136 \mathrm{~mol})$ was slowly added over a period of 30-40 min. The solid phenyl acetyl chloride was collected.

\section{Product 1:}

$10.0 \mathrm{ml}$ of $20 \% \mathrm{w} / \mathrm{v}$ phenyl acetyl chloride in ethanol was added gradually to $10 \mathrm{~g}$ pectin under stirring over a period of $2 \mathrm{hrs}$. Reaction product was collected, washed and dried in a hot air oven at $37^{\circ} \mathrm{C}$.

\section{Product 2:}

A weighed quantity of $10.0 \mathrm{~g}$ of pectin was gradually added into a flask containing $10 \mathrm{ml}$ of $20 \% \mathrm{w} / \mathrm{v}$ phenyl acetyl chloride in ethanol over a period of $1 \mathrm{~h}$ under continuous stirring. The reaction product was collected, washed and dried in a hot air oven at $37^{\circ} \mathrm{C}$.

\section{Physicochemical characterization:}

The pectin modified by the above methods was characterized by the following parameters.

1) Gelling or swelling factor:

Distilled water was added gradually to $100.0 \mathrm{mg}$ of modified pectin on a watch glass till no further absorption could be visibly observed. The swelling index/gelling capacity of the modified pectin was determined by the difference in the weight of watch glass before and after addition and absorption of water. Data for this gelling or swelling factor are given in Table 1.

2) Solubility in distilled water, chloroform and methanol:

A weighed quantity of $100 \mathrm{mg}$ of non-modified or modified pectin was added to $10 \mathrm{ml}$ of particular solvent in a $50 \mathrm{ml}$ beaker and was shaken for $24 \mathrm{hrs}$ on an orbital shaker. Then the solution was filtered through already weighed Whatman filter paper No. 41 and the paper was re-weighed after complete drying. The solubility of the modified pectin in a particular solvent was determined by the difference between the final weight and initial weight of paper. Solubility data of the modified pectins is given in the Table 2.

\section{Selection of modified pectin for formulation design}

On the basis of data obtained from the physicochemical characterization of the modified pectins, we have selected product 1 from method $B$ for further studies because of its decreased solubility in distilled water but its retaining swelling characters to a desired extent. This chemically modified pectin was used for formulation design to ascertain the release kinetics of ibuprofen from the designed formulation. The release kinetics were in accordance with the anticipations based on the physicochemical characterization of the chemically modified polymer. 


\section{Physicochemical characterization of selected modified pectin:}

Determination of acid value:

The acid value is the number which expresses in milligrams the amount of potassium hydroxide necessary to neutralize the free acid present in 1 gram of the substance.

For this purpose, $10.0 \mathrm{~g}$ polymer was dissolved in $50 \mathrm{ml}$ of a mixture of equal volumes of ethanol (95\%) and ether, previously neutralized with $0.1 \mathrm{M}$ potassium hydroxide to phenolphthalein solution. To dissolve the sample in cold solvent, the flask was connected with reflux condenser and warmed slowly with frequent shaking. $1.0 \mathrm{ml}$ of phenolphthalein solution was added and titrated with $0.1 \mathrm{M}$ potassium hydroxide until the solution remained faintly pink after shaking for $30 \mathrm{sec}$. The acid value was calculated from the expression: Acid value $=5.61 \mathrm{n} / \mathrm{w}$, where $\mathrm{n}$ is the number of $\mathrm{ml}$ of $0.1 \mathrm{M}$ potassium hydroxide required and $\mathrm{w}$ is the weight, in $\mathrm{g}$, of the substance.

Saponification value:

The saponification value is the number of milligrams of potassium hydroxide necessary to neutralize the free acid and to saponify the esters present in $1 \mathrm{~g}$ of the sample.

At this, $1.0 \mathrm{~g}$ polymer was taken into a $200 \mathrm{ml}$ flask of borosilicate glass fitted with a reflux condenser. $25.0 \mathrm{ml} 0.5 \mathrm{M}$ ethanolic potassium hydroxide solution and a little pumice powder was added and boiled under reflux on a water-bath for 30 minutes. $1.0 \mathrm{ml}$ of phenolphthalein solution was added and titrated immediately with $0.5 \mathrm{M}$ hydrochloric acid $(a \mathrm{ml})$. For the blank, the experiment was repeated in absence of polymer $(\mathrm{b} \mathrm{ml})$.

The saponification value was calculated from the expression: saponification value $=28.05$ $(b-a) / w$, where $w$ is the weightof the polymer $(g)$.

\section{Ester value:}

Ester value is the amount of potassium hydroxide $(\mathrm{mg})$ required to saponify the esters present in $1 \mathrm{~g}$ of the sample.

The ester value was calculated from the expression:

ester value $=$ Saponification value - Acid value

\section{Preparation of starch paste}

Starch was used as binder. Starch paste was prepared by dispersing starch in sufficient cold purified water to make a $5 \% \mathrm{w} / \mathrm{w}$ suspension and warming in a water bath with continuous stirring until a translucent paste formed.

\section{Preparation of matrix tablets}

Matrix tablets containing $200 \mathrm{mg}$ of ibuprofen, modified pectin and HPMC $\mathrm{K} 100 \mathrm{M}$ at varying ratios were prepared by a wet granulation/compression method using $5 \%(w / v)$ starch paste $(0.33 \mathrm{mg} / \mathrm{tablet})$ as a binder. 
Tab. 7. Composition details of modified pectin and HPMC matrix tablet*:

\begin{tabular}{|c|c|c|c|c|}
\hline \multirow{2}{*}{$\begin{array}{l}\text { Formulation } \\
\text { No }\end{array}$} & \multicolumn{2}{|c|}{ Ingredients (mg) } & \multirow[b]{2}{*}{$\begin{array}{l}\text { HPMC K100M } \\
\text { (Coded level) }\end{array}$} & \multirow[b]{2}{*}{$\begin{array}{l}\text { Modified Pectin } \\
\text { (Coded Level) }\end{array}$} \\
\hline & Ibuprofen & Lactose & & \\
\hline B1 & $200 \mathrm{mg}$ & $20 \mathrm{mg}$ & +1 & +1 \\
\hline B2 & $200 \mathrm{mg}$ & $20 \mathrm{mg}$ & +1 & -1 \\
\hline B3 & $200 \mathrm{mg}$ & $20 \mathrm{mg}$ & -1 & -1 \\
\hline B4 & $200 \mathrm{mg}$ & $20 \mathrm{mg}$ & -1 & 0 \\
\hline B5 & $200 \mathrm{mg}$ & $20 \mathrm{mg}$ & 0 & +1 \\
\hline B6 & $200 \mathrm{mg}$ & $20 \mathrm{mg}$ & +1 & 0 \\
\hline B7 & $200 \mathrm{mg}$ & $20 \mathrm{mg}$ & 0 & 0 \\
\hline B8 & $200 \mathrm{mg}$ & $20 \mathrm{mg}$ & 0 & -1 \\
\hline B9 & $200 \mathrm{mg}$ & $20 \mathrm{mg}$ & -1 & +1 \\
\hline
\end{tabular}

${ }^{*}$ Concentration of HPMC and modified pectin is given as $\%$ w/w of ibuprofen concentration in compacts.

$+1=20 \%,-1=10 \%$ and $0=0 \% \mathrm{w} / \mathrm{w}$ of ibuprofen

First, ingredients including ibuprofen, HPMC K100M, modified pectin, and lactose were mixed homogeneously. Then $5 \%$ of starch paste were added to obtain a wet mass. The wet mass was forced through a 20-mesh sieve and dried at $40{ }^{\circ} \mathrm{C}$ for $12 \mathrm{hrs}$. The dried granules were lubricated with $1 \%(\mathrm{w} / \mathrm{w})$ magnesium stearate in and compressed into flat 8 $\mathrm{mm}$ tablets using single punch press. The composition of the formulations are given in Table 7 and their characteristics in Table 5.

\section{Ibuprofen release studies}

Factorial designs $3^{2}$ for concentration of HPMC and concentration of modified pectin was applied to check the dissolution studies of 9 batches prepared. The concentration of HPMC and modified pectin are given as $\% \mathrm{w} / \mathrm{w}$ of ibuprofen concentration in the tablets. The data of factorial design are presented in Table 7 . The tablets prepared on single punch press by blending modified pectins, HPMC K100M and other excipients were evaluated for their integrity in the physiological environment of stomach and intestine under conditions mimicking mouth-to-colon transit. These studies were carried out according to USP XXIII, using USP apparatus type II (model TDT-08L, Electrolab, India) apparatus 1 at 50 rpmand $37.5 \pm 0.5^{\circ} \mathrm{C}$. The dissolution media, $0.1 \mathrm{~N} \mathrm{HCl}$ and phosphate buffer $\mathrm{pH}$ 6.8, were prepared according to the Indian Pharmacopoeia 1996 [16-17]. The tablets were tested for drug release for $2 \mathrm{hrs}$ in $0.1 \mathrm{~N} \mathrm{HCl}(900 \mathrm{ml})$ as the average gastric emptying time is about $2 \mathrm{hrs}$. After this, all the $0.1 \mathrm{~N} \mathrm{HCl}$ was replaced by $900 \mathrm{ml}$ of phosphate buffer $\mathrm{pH} 6.8$ as a dissolution media and the study was continued for $6-8 \mathrm{hrs}$ representing the average intestinal transit time. In intervals of one hour, $5 \mathrm{ml}$ samples were withdrawn and replenished with $5 \mathrm{ml}$ of fresh dissolution medium to maintain the sink conditions. The samples were filtered through a Whatman filter paper No. 41 and the filtrate was analyzed photometrically for the ibuprofen content at $263 \mathrm{~nm}$ after suitable dilution. The method described by Bamba et al. was adapted to ascertain kinetics of drug release [6]. These data from the in vitro drug release were analyzed by different kinetic models in order to evaluate the release mechanism of ibuprofen from the matrices (Table 8). 
Tab. 8. Applied mathematical models to the dissolution data of ibuprofen matrix tablets*:

\begin{tabular}{ll}
\hline Function & Equation \\
\hline Zero order & $\%$ released $=\mathrm{kt}$ \\
First order & Log \% unreleased $=[\mathrm{k} / 2.303] \mathrm{t}$ \\
Hixson-Crowell & $(\%$ unreleased $) 1 / 3=\mathrm{kt}$ \\
Higuchi matrix & $\%$ released $=\mathrm{kt}^{0.5}$ \\
Korsmeyer-Peppas & $\%$ released $=\mathrm{kt}^{\mathrm{n}}$ \\
\hline
\end{tabular}

${ }^{*} \mathrm{k}$, dissolution rate constant; $\mathrm{n}$, release exponent which is indicative of drug release mechanism; $t$, time at which $\%$ of drug released.

The dissolution data (Table 7) were processed with software PCP-Disso-v2.08 developed by Poona College of Pharmacy (Pune). The r-value (coefficient of correlation) was employed to select the most appropriate kinetic model.

\section{Acknowledgements}

The authors are grateful to the Principal, Bharati Vidyapeeth College of Pharmacy, Kolhapur for providing the necessary help for this work. We are also thankful to the Block Pharmaceutical, Kolhapur for providing the ibuprofen and the Krishna Pectins Pvt. Ltd. Jalgaon for supplying the pectin.

\section{Authors' Statement}

\section{Competing Interests}

The authors declare no conflict of interest.

\section{References}

[1] Liu L S., Fishman M L, Kost J, Hicks K B.

Pectin-based systems for colon-specific drug delivery via oral route.

Biomaterials. 2003; 24: 3333-3343.

doi:10.1016/S0142-9612(03)00213-8

[2] Ugurlu T, Turkoglu M, Gurer U S, Akarsu B G.

Colonic delivery of compression coated nisin tablets using pectin/HPMC polymer mixture.

Eur J Pharm Biopharm. 2007; 67: 202-210.

doi:10.1016/j.ejpb.2007.01.016

[3] International Pectin Producers Association http://www.ippa.info

[4] Cybercolloids Ltd. http://www.cybercolloids.net/library/pectin/properties.php (accepted 26 May 2005)

[5] Kudela V

Hydrogels Encyclopedia of Polymer Science and Engineering.

Wiley, New York. 1987; 7: 703-807.

[6] Bamba M, Puisieux F.

Release mechanism in gel forming sustained release preparation.

Int J Pharm. 1979; 2: 307-315.

doi:10.1016/0378-5173(79)90037-1 
[7] Sande S A.

Pectin-based oral drug delivery to the colon.

Expert Opin Drug Deliv. 2005; 2: 441-450.

doi:10.1517/17425247.2.3.441

[8] Baojian W, Daoyin D, Yi L, Wei W.

Biphasic release of indomethacin from HPMC/Pectin/Calcium matrix tablet : II. Influencing Variables, stability and Pharmacokinetics in dogs.

Eur J Pharm Biopharm. 2008; 69: 294-302.

doi:10.1016/j.ejpb.2007.10.001

[9] Sinha V R, Kumria R.

Microbiologically triggered drug delivery to the colon.

Eur J Pharm Sci. 2003; 18: 3-18.

doi:10.1016/S0928-0987(02)00221-X

[10] Ofari-Kwakye K, Fell J T.

Leaching of pectin from mixed films containing pectin, chitosan and HPMC intended for biphasic drug delivery.

Int J Pharm. 2003; 250: 251-257.

doi:10.1016/S0378-5173(02)00546-X

[11] Ahrabi S F, Madsen G, Dyrstadb K, Sandea S A, Graffner C.

Development of pectin matrix tablets for colonic delivery of model drug ropivacaine.

Eur J Pharm Sci. 2000; 10: 43-52.

doi:10.1016/S0928-0987(99)00087-1

[12] Macleod G S, Fell J T, Collett J H, Sharma H L, Smith A-M.

Selective drug delivery to the colon usng pectin:chitosan:hydroxypropyl methylcellulose film coated tablets.

Int J Pharm. 1999; 187: 251-257.

doi:10.1016/S0378-5173(99)00196-9

[13] Wakerly Z, Fell J T, Attwood D, Parkins D A.

In vitro evaluation of pectin based colonic drug delivery systems.

Int J Pharm. 1996; 129: 73-77.

doi:10.1016/0378-5173(95)04251-2

[14] Kupchik L A, Kartel N T, Bogdanov E S, Bogdanov O V, Kupchik M P. [Chemical modification of pectin to improve its sorption properties].

Zh Prikl Khim. 2006; 79: 464-467.

Russ J Appl Chem. 2006; 79: 457-460.

doi:10.1134/S1070427206030256

[15] Dongowski G, Schnorrenberger B, Pitzer M, Schwarz M, Neubert R. Interaction between food components and drugs. Part 5: Effect of acetylation and amidation of pectins on the interaction with drug.

Int J Pharm. 1997; 158: 99-107.

doi:10.1016/S0378-5173(97)00252-4

[16] United State of Pharmacopoeia 23, 1791.

[17] Indian pharmacopoeia, Vol. II, Appendix 13.1 \& 13.5, A-147 \& A-211, (1996). 